\title{
Repair or replace the mitral valve for severe ischemic mitral regurgitation?
}

\author{
V Shumavets', A Shket, A Janushko, V Sevrukevich, I Grinchuk, S Kurganovich, N Semenova, Y Ostrovski \\ From 23rd World Congress of the World Society of Cardio-Thoracic Surgeons \\ Split, Croatia. 12-15 September 2013
}

\section{Background}

We focused our study on patients with severe compromised ischemic left ventricle and functional mitral regurgitation to understand how mitral valve replacement versus repair affects survival and provide the predictors of hospital and long-term mortality.

\section{Methods}

870 patients (mean age, $57,9 \pm 8,3$ years) from 2000 to 2012 , with coronary artery diseases and significant ischemic mitral regurgitation $(>2)$ were operated - in 787pts CABG+MV repair were performed and in 83 pts MV replacement were combined with CABG. Groups were matched by propensity score using demographics dates, co-morbidity, LV remodeling and MR grade by quantitative echocardiography. Survival (with mean follow-up 5,3 $\pm 1,6$ years) and NYHA functional class were compared. The impact of mitral valve replacement versus repair on survival by comparing theses propensity matched subgroups was analyzed.

\section{Results}

Follow-up was $100 \%$ complete. Before matching 10-year survival was significantly worse in replacement group (long-rank $\mathrm{p}=0,003)$. After propensity matching 1:2 we've received homogenous cohort of 99 pts with severe compromised LV (EDD 71,8 \pm 7,6 mm, ESD $59 \pm 8,1$ $\mathrm{mm}$, iEDV $131 \pm 28,1 \mathrm{ml} / \mathrm{m} 2$ with EF $31,3 \pm 3,7 \%$ ) and severe MR. The fact of mitral valve replacement versus repair did not influence survival (long-rank $\mathrm{p}=0,443$ ) and overall in 1 - and 5 -year it were $91,8 \pm 0,14 \%$ and $69,2 \pm 0,48 \%$ respectively. The independent risk factors for an increased mortality within the five years of surgery in multivariate propensity-matched analyses were found LV ESD (HR-1,085, 95\% CI 1,018-1,157, p=0,013),

\footnotetext{
* Correspondence: vshumaviec@gmail.com

Cardiac Surgery Department, Belarus Cardiology Centre, Minsk, Belarus
}

chronic renal disease (HR-1,8, 95\% CI 1,34-2,45 $\mathrm{p}=$ 0,012 ), use of IABP during hospital period (HR-3,147, 95\% CI 1,17-8,4, $\mathrm{p}=0,022)$ and age $(\mathrm{HR}-0,936,95 \% \mathrm{CI}$ $0,876-1,0, \mathrm{p}=0,011)$.

\section{Conclusion}

The mitral valve replacement versus repair did not seem to affect survival in patients with severe damaged ischemic LV and it mostly depends on factors related to the patient's condition at the time of surgery.

Published: 11 September 2013

doi:10.1186/1749-8090-8-S1-O213

Cite this article as: Shumavets et al:: Repair or replace the mitral valve

for severe ischemic mitral regurgitation? Journal of Cardiothoracic Surgery 2013 8(Suppl 1):O213.
Submit your next manuscript to BioMed Central and take full advantage of:

- Convenient online submission

- Thorough peer review

- No space constraints or color figure charges

- Immediate publication on acceptance

- Inclusion in PubMed, CAS, Scopus and Google Scholar

- Research which is freely available for redistribution
C Biomed Central (c) 2013 Shumavets et al; licensee BioMed Central Ltd. This is an Open Access article distributed under the terms of the Creative Commons Attribution License (http://creativecommons.org/licenses/by/2.0), which permits unrestricted use, distribution, and reproduction in any medium, provided the original work is properly cited. 